\title{
Clevudine Demonstrates Potent Antiviral Activity in Naïve Chronic Hepatitis B Patients
}

\author{
June Sung Lee ${ }^{a}$ Eun Taek Park ${ }^{b}$ Seung Sik Kang ${ }^{c}$ Eun Sil Gu ${ }^{d}$ Jong Sun Kim ${ }^{e}$ \\ Dong Seob Jang ${ }^{f}$ Kyoung Seog Lee ${ }^{g}$ Jae-Su Lee ${ }^{h}$ Nung Hwa Park ${ }^{i}$ Chang Hwang Bae ${ }^{j}$ \\ Soon Koo Baik ${ }^{k}$ Byeong Jeon Yu' Soon Hyung Lee ${ }^{m}$ Eun Jong Lee ${ }^{n}$ Sung II Park ${ }^{\circ}$ \\ Myoung Bae ${ }^{p}$ Jung Woo Shin ${ }^{q}$ Jae Hong Choir ${ }^{r} \mathrm{Chul} \mathrm{Gu}^{\mathrm{s}}$ Sin Kil Moon ${ }^{\mathrm{t}}$ Gab Jin Chun ${ }^{\mathrm{u}}$ \\ Ju Hyun Kim ${ }^{v}$ Hong Soo Kim w Sung-Kyu Choi ${ }^{\mathrm{x}}$ \\ ${ }^{a}$ Inje University Ilsanpaik Hospital, Goyang, ${ }^{b}$ Inje University Paik Hospital, Busan, ' $Y e g i$ Clinic, Seoul, \\ dHyoin Medical Clinic, Incheon, eYonsei Somang Internal Medicine Clinic, Gympo, ${ }^{f}$ Serim Hospital, Bupyung, \\ ${ }^{9}$ Han Ma Eum Medical Center, Changwon, h'Lee Jae-su Internal Medicine Clinic, Chongju, 'Ulsan University \\ Hospital, Ulsan, ${ }^{j}$ Hopyung Asan Medical Clinic, Namyangju, ${ }^{k}$ Yonsei University Wonju College of Medicine, Wonju, \\ 'Yu Byeong Jeon Internal Medicine Clinic, Gwangju, mLee Soon Hyung Internal Medicine Clinic, Jeonju, \\ ${ }^{\mathrm{n} L e e ~ E u n ~ J o n g ~ I n t e r n a l ~ M e d i c i n e ~ C l i n i c, ~ D o n g d u ~ C h e o n, ~}{ }^{\circ}$ Donggunsan Hospital, Gunsan, ${ }^{\mathrm{P}}$ Hanil Hospital, \\ Gwangju, 9 Ulsan University Hospital, Ulsan, 'rHanmaum Medical Foundation Hana Hospital, Chongju,

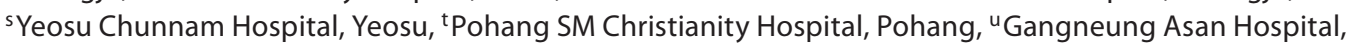 \\ Gangneung, ${ }^{\vee}$ Gachon University Gil Hospital, Incheon, "'Soonchunhyang University, Chunan, and \\ ${ }^{x}$ Chonnam National University Hospital, Gwangju, Korea
}

\section{Key Words}

Hepatitis B virus · Post marketing surveillance •

Viral replication $\cdot$ Viral breakthrough $\cdot$ Clevudine

\begin{abstract}
Objectives: Clevudine has demonstrated antiviral potency in the treatment of naïve chronic hepatitis B patients in pivotal studies. The objectives of this study were to evaluate the safety and efficacy of a 1-year treatment with clevudine in chronic hepatitis B patients. Methods: This is a post-marketing surveillance using case report forms which were submitted to the health authorities. Results: Analysis of individual data showed that hepatitis B virus (HBV) DNA after a 1-year treatment was $<141,500$ copies $/ \mathrm{ml}$ in $96 \%$ of hepatitis B e antigen (HBeAg)-positive and $100 \%$ of $\mathrm{HBeAg}$-negative patients. The proportion of patients with HBV DNA $<2,000$ copies $/ \mathrm{ml}$ after a 1-year treatment was $74 \%: 71 \%$ of HBeAg-positive and $93 \%$ of $\mathrm{HBeAg}$-negative patients. Most of the patients with HBV DNA below the detection limit with each
\end{abstract}

assay at week 24 showed sustained viral suppression up to week 48. The proportion of patients who showed normal alanine aminotransferase at week 48 was $86 \%$ in HBeAgpositive patients and $87 \%$ in $\mathrm{HBeAg}$-negative patients. The rates of $\mathrm{HBeAg}$-loss were $21 \%$. Two patients showed viral breakthrough during treatment. Conclusion: Clevudine monotherapy demonstrates potent antiviral activity as well as biochemical and serological response with a $0.7 \%$ rate of viral breakthrough in naïve chronic hepatitis $B$ patients.

Copyright $\odot 2009$ S. Karger AG, Basel

\section{Introduction}

Although effective vaccines are available in many countries, hepatitis B virus (HBV) infection is common and a major worldwide health threat. Chronic hepatitis B patients are at high risk of progression to cirrhosis, endstage liver disease and primary hepatocellular carcinoma, which is associated with considerable mortality [1].

\section{KARGER}

Fax +4161306 1234 E-Mail karger@karger.ch www.karger.com
(C) 2009 S. Karger AG, Basel

0300-5526/10/0532-0083\$26.00/0

Accessible online at:

www.karger.com/int
Sung-Kyu Choi

Department of Internal Medicine

Chonnam National University Hospital

671 Jebongno Donggu, Gwangju 501-757 (Korea)

Tel. +8262 220 6203, Fax +8262 225 8578, E-Mail choisk@ chonnam.ac.kr 
Approximately $15-40 \%$ of infected subjects will develop cirrhosis, liver failure or hepatocellular carcinoma [2].

Several oral antiviral agents are used for chronic HBV infection. Lamivudine has been shown to improve shortterm outcome in some patients [3]. However, these treatments do not provide a cure or durable remission in the majority of patients. Lamivudine has a favorable safety profile; however, long-term therapy is required, which can lead to the selection of drug-resistant mutants $[4,5]$. Adefovir dipivoxil and entecavir have the advantage of retaining antiviral activity against lamivudine-resistant HBV isolates and a lower risk of developing drug-resistant mutants [6, 7]. However, adefovir dipivoxil and entecavir also require long-term therapy, and discontinuation of therapy is associated with a prompt relapse to disease activity. An ideal regimen should be safe with more potent and sustained viral suppression, with a minimal chance of developing resistant mutants.

Clevudine [1-(2-deoxy-2-fluoro- $\beta$-L-arabinofuranosyl) thymine, L-FMAU], which is being marketed in Korea, is a nucleoside analogue of the unnatural $\beta-\mathrm{L}$ configuration that has potent activity against $\mathrm{HBV}$ and some activity against the Epstein-Barr virus in vitro [8]. The lack of cytotoxicity reflects the inability of human cellular DNA polymerases $\alpha, \beta, \gamma$ and $\delta$ to utilize the $5^{\prime}$-triphosphate of clevudine as a substrate [9]. Moreover, clevudine was found to have no effect on mitochondrial structure, DNA content or function [9].

A unique advantageous characteristic of clevudine is the prolonged and sustained suppression of viral replication even after withdrawal of treatment. Serum woodchuck hepatitis virus (WHV) DNA remained undetectable for up to 56 weeks after WHV-infected animals were given oral doses of clevudine $(10 \mathrm{mg} / \mathrm{kg}$ daily) for 12 weeks [10]. It has been demonstrated that the sustained viral suppression is associated with a significant reduction of covalently closed circular DNA in hepatocytes [11].

In the pivotal phase III clinical trials $[12,13]$, clevudine demonstrated potent antiviral efficacy and significant biochemical improvement after 24 weeks of therapy. In hepatitis $\mathrm{B}$ e antigen ( $\mathrm{HBeAg}$ )-positive chronic hepatitis B patients, clevudine $(30 \mathrm{mg})$ produced highly potent antiviral activity $\left[-5.1 \log _{10}\right.$ copies $/ \mathrm{ml}$ change from baseline, $59 \%$ with negative HBV DNA ( $<300$ copies $/ \mathrm{ml})$ by PCR at the end of 24-week treatment] and biological improvement leading to alanine aminotransferase (ALT) normalization (68\% at week 24). In HBeAg-negative chronic hepatitis B patients, $92 \%$ of the patients had negative HBV DNA by PCR and 75\% had normal ALT at the end of 24 weeks of treatment. As already observed in animal models and in the previous clinical trials [14-16], sustained viral suppression and biochemical improvement were observed at 6 months post-treatment in these studies.

We describe here the results of 48 weeks of clevudine treatment to see the viral suppression potency and resistance profile.

\section{Patients and Methods}

Post-marketing surveillance was performed to evaluate the safety and efficacy of clevudine in the naïve chronic hepatitis $B$ patients. The protocol and case report form was approved by the health authorities before starting.

Patients who started clevudine monotherapy between February 2007 and June 2007 were included in this surveillance. Efficacy parameters included serum HBV DNA, ALT and serology for $\mathrm{HBeAg}$.

For the detection of HBV DNA values, CMHA [Hybrid Capture II Kit; Digene, Gaithersburg, Md., USA; limit of detection (LOD) of 141,500 copies/ml, 63 patients], bDNA (Bayer HealthCare LLC, Tarrytown, N.Y., USA; LOD of 2,000 copies/ml, 156 patients) and PCR [LOD of 125 copies/ml by real-time PCR and 300 copies/ml by Amplicor PCR (Roche Molecular Systems, Branchburg, N.J., USA); 125 patients] were used. Laboratory tests were measured at each clinical site. The proportion of patients with HBV DNA <141,500 copies/ml and <2,000 copies/ml were evaluated. At each time-point, patients with missing data were excluded from the analysis at that time-point.

Biochemical response was defined as a normalization of serum ALT. Serological response was assessed during the surveillance period. HBeAg-loss was defined as the disappearance of $\mathrm{HBeAg}$, and $\mathrm{HBeAg}$ seroconversion was defined as $\mathrm{HBeAg}$ disappearance combined with the appearance of anti-HBe [16].

Viral breakthrough, which was defined as $1 \log _{10}$-increase from nadir, was assessed during treatment. For the evaluation of viral breakthrough, patients using CMHA for HBV DNA titration were excluded due to the LOD.

The safety analysis included all adverse events, serious adverse events and laboratory abnormalities which were recorded over 1 year. The safety evaluation was evaluated every 4 weeks and efficacy evaluation was scheduled every 12 weeks.

\section{Results}

\section{Patients}

The data from the 344 patients treated with clevudine (30 mg) from several hospitals and clinics were collected and analyzed. Among them, 274 patients were HBeAgpositive and 70 patients were $\mathrm{HBeAg}$-negative before clevudine treatment. All patients were Korean, of which 229 (67\%) were male and 115 (33\%) were female. All patients, except 10 (3 HBeAg-positive, $7 \mathrm{HBeAg}$-negative), 
showed HBV DNA levels of more than 141,500 copies/ml before clevudine treatment.

The majority of patients (98\%) had ALT values more than the upper limit of normal before clevudine treatment.

Sixty-three patients did not finish treatment: 1 because of viral breakthrough, 35 because of patient withdrawal, 25 because of financial difficulty and 2 due to loss of follow-up.

\section{Antiviral Activity}

Table 1 displays the efficacy data. The proportion of patients with HBV DNA $<141,500$ copies/ml after a 1year treatment was 96\%: $96 \%$ of $\mathrm{HBeAg}$-positive and $100 \%$ of HBeAg-negative. The proportion of patients with HBV DNA <2,000 copies/ml after the 1-year treatment was $74 \%$ : $71 \%$ of $\mathrm{HBeAg}$-positive and $93 \%$ of $\mathrm{HBeAg-negative.}$

After the 1-year clevudine therapy, $3 \%$ of the patients experienced treatment failure. All of them were $\mathrm{HBeAg}$ positive at baseline. In this surveillance, treatment failure was defined as not achieving a $>2 \log _{10}$-decrease from baseline and maintaining a HBV DNA level over the LOD for 1 year.

Ninety-two percent of the patients who showed HBV DNA below the detection limit with each assay at week 24 showed sustained viral suppression up to week 48 .

At baseline, median ALT was 116.5 IU/l. After the 1year treatment, $86 \%$ of HBeAg-positive and $87 \%$ of HBeAg-negative patients had normal ALT. HBeAg-loss was observed in $21 \%$, and $13 \%$ had $\mathrm{HBeAg}$ seroconversion.

Two patients (0.7\%) showed viral breakthrough (1 $\log _{10}$-increase from the nadir during treatment) during therapy.

During the 1-year treatment, 7 patients (3\%) experienced $>5$-times the upper limit of normal in ALT, which resolved without any special treatment. Adverse events reported during the 1-year treatment were ALT elevation and creatine elevation, both of which resolved without any treatment.

\section{Discussion}

Clevudine (30 mg once daily) produced highly potent antiviral activity and biochemical improvement in naïve chronic hepatitis B patients when used as monotherapy.

Clevudine exerted potent viral suppression from baseline in serum HBV DNA, leading to a high proportion of
Table 1. Summary of serum HBV DNA and ALT response

\begin{tabular}{cccc}
\hline & \multirow{2}{*}{ Total } & \multicolumn{2}{l}{ Clevudine 30 mg } \\
\cline { 3 - 4 } & \multicolumn{4}{c}{$\begin{array}{l}\text { HBeAg- } \\
\text { positive }\end{array}$} & $\begin{array}{l}\text { HBeAg- } \\
\text { negative }\end{array}$ \\
\hline \multicolumn{4}{c}{ Serum HBV DNA $<141,500$ copies/ml } \\
Week 12 & $171 / 288(59)$ & $128 / 236(54)$ & $43 / 52(83)$ \\
Week 24 & $213 / 274(78)$ & $178 / 236(75)$ & $35 / 38(92)$ \\
Week 36 & $235 / 256(92)$ & $199 / 220(91)$ & $36 / 36(100)$ \\
Week 48 & $246 / 256(96)$ & $215 / 225(96)$ & $31 / 31(100)$ \\
Serum HBV DNA $<2,000$ copies/ml & & \\
Week 12 & $65 / 232(28)$ & $42 / 184(23)$ & $23 / 48(48)$ \\
Week 24 & $113 / 219(52)$ & $86 / 186(46)$ & $27 / 33(82)$ \\
Week 36 & $143 / 205(70)$ & $116 / 174(67)$ & $27 / 31(87)$ \\
Week 48 & $152 / 206(74)$ & $127 / 179(71)$ & $25 / 27(93)$ \\
Normal ALT & \multicolumn{4}{c}{} & \\
Week 12 & $142 / 292(49)$ & $95 / 233(41)$ & $47 / 59(80)$ \\
Week 24 & $194 / 285(68)$ & $161 / 245(66)$ & $33 / 40(83)$ \\
Week 36 & $207 / 264(78)$ & $176 / 225(78)$ & $31 / 39(80)$ \\
Week 48 & $232 / 271(86)$ & $200 / 234(86)$ & $32 / 37(87)$ \\
\hline
\end{tabular}

Figures in parentheses represent percentages.

patients (96\% in $\mathrm{HBeAg}$-positive and $100 \%$ in $\mathrm{HBeAg}$ negative patients) achieving serum HBV DNA levels $<141,500$ copies/ml. Seventy-one percent of the HBeAgpositive patients and $93 \%$ of the $\mathrm{HBeAg}$-negative patients had HBV DNA $<2,000$ copies $/ \mathrm{ml}$.

It is known that the viral response at week 24 is a predictor of viral response during long-term therapy [17]. Our results also showed that $92 \%$ of the patients with viral suppression up to the detection limit with each assay at week 24 maintained viral response up to week 48 . Most of the patients who showed HBV DNA below the detection limit with each assay at week 24 showed sustained viral suppression up to week 48 .

In addition, clevudine showed a good biochemical and serological response after the 1-year treatment. Eightysix percent of the patients showed normal ALT after the 1 -year treatment and, with the exception of 3 patients, all patients showed ALT values $\leq 2 \times$ ULN after the 1-year treatment. Furthermore, $21 \%$ of the patients had HBeAgloss and $13 \%$ had $\mathrm{HBeAg}$ seroconversion after the 1-year treatment.

Two patients $(0.7 \%)$ showed viral breakthrough (1 $\log _{10}$-increase from the nadir during treatment) during the 1-year treatment. One of them showed viral suppression to $<300$ copies/ml at week 24 and then viral breakthrough to 5,310 copies/ml at week 48 with normal ALT. 
In the pivotal phase III trials $[12,13]$, no clevudine resistance was observed during the 24 -week treatment. During the 1 -year treatment in this surveillance, $0.7 \%$ showed viral breakthrough, which demonstrates that the emergence of resistance with clevudine is very low for 1 year.

In this surveillance, 37 patients with cirrhosis (compensated or decompensated) were included. Among the 12 cirrhotic patients who completed the 1-year treatment, 10 showed viral suppression to the LOD and normal ALT after the 1-year treatment. Twenty-five patients discontinued the surveillance due to financial difficulty without relation to clevudine, as they were not covered by the insurance system in the early phase of clevudine marketing. These results prove that clevudine also shows very rapid and potent viral suppression in hepatitis B-related cirrhosis patients, even though only a small number of patients were included in this surveillance. Further studies on a larger scale may be needed to clarify the safety of clevudine in patients with cirrhosis. In conclusion, our data showed that clevudine seems to be one of the most potent antiviral agents among the agents currently being marketed [18-20]. Clevudine's strong viral suppression and low rate of resistance development would be very helpful in the treatment of chronic hepatitis B patients.

\section{References}

1 Pratt D: Developments in the management of hepatitis B. http://www.medscape.com/ viewarticle/495209 (accessed August 30, 2005).

$\checkmark 2$ Lok AS: Chronic hepatitis B. N Engl J Med 2002;346:1682-1683.

>3 Dienstag JL, Schiff ER, Wright TL, Perrillo RP, Hann HW, Goodman Z, Crowther L, Condreay LD, Woessner M, Rubin M, Brown NA: Lamivudine as initial treatment for chronic hepatitis B in the United States. N Engl J Med 1999:341:1256-1263.

$\checkmark 4$ Leung NW, Lai CL, Chang TT, Guan R, Lee CM, Ng KY, Lim SG, Wu PC, Dent JC, Edmundson S, Condreay LD, Chien RN: Extended lamivudine treatment in patients with chronic hepatitis B enhances hepatitis $\mathrm{B}$ e antigen seroconversion rates: results after 3 years of therapy. Hepatology 2001;33:15271532.

5 Lau DT, Kohkhar MF, Doo E, Ghany MG, Herion D, Park Y, Kleiner DE, Schmid P, Condreay LD, Gauthier J, Kuhns MC, Liang TJ, Hoofnagle JH: Long-term therapy of chronic hepatitis B with lamivudine. Hepatology 2000;32:828-834.

6 Perrilo R, Schiff E, Yoshida E, Statler A, Hirsch K, Wright T, Gutfreund K, Lamy P, Murray A: Adefovir dipivoxil for the treatment of lamivudine-resistant hepatitis B mutants. Hepatology 2000;32:129-134.

7 Chang TT, Gish RG, Hadziyannis SJ, Cianciara J, Rizzetto M, Schiff ER, Pastore G, Bacon BR, Poynard T, Joshi S, Klesczewski KS, Thiry A, Rose RE, Colonno RJ, Hindes RG; BEHOLD Study Group: A dose-ranging study of the efficacy and tolerability of entecavir in lamivudine-refractory chronic hepatitis B patients. Gastoenterology 2005;129: 1198-1209.

$\checkmark 8$ Chu CK, Ma T, Shanmuganathan K, Wang C, Xiang Y, Pai SB, Yao GQ, Sommadossi JP, Cheng YC: Use of 2'-fluoro-5-methyl- $\beta$-Larabinofuranosyluracil as a novel antiviral agent for hepatitis B virus and Epstein-Barr virus. Antimicrob Agents Chemother 1995 39:979-981.

-9 Pai SB, Liu SH, Zhu YL, Chu CK, Cheng YC: Inhibition of hepatitis $\mathrm{B}$ virus by a novel $\mathrm{L}$ nucleoside, 2'-fluoro-5-methyl- $\beta$-L-arabinofuranosyluracil. Antimicrob Agents Chemother 1996;40:380-386

10 Chu CK, Boudinot FD, Peek SF, Hong JH, Choi Y, Korba BE, Gerin JL, Cote PJ, Tennant $\mathrm{BC}$, Cheng YC: Preclinical investigation of L-FMAU as an anti-hepatitis B virus agent. Antivir Ther 1998;3(suppl 3):113-121.

11 Summers J, Mason WS: Residual integrated viral DNA after hepadnavirus clearance by nucleoside analog therapy. Proc Natl Acad Sci USA 2004;101:638-640.

12 Yoo BC, Kim JH, Chung YH, Lee KS, Paik SW, Ryu SH, Han BH, Han JY, Byun KS, Cho M, Lee HJ, Kim TH, Cho SH, Park JW, Um SH, Hwang SG, Kim YS, Lee YJ, Chon CY, Kim BI, Lee YS, Yang JM, Kim HC, Hwang JS, Choi SK, Kweon YO, Jeong SH, Lee MS, Choi JY, Kim DG, Kim YS, Lee HY, Yoo K, Yoo HW, Lee HS: A 24-week clevudine therapy showed potent and sustained antiviral activity in $\mathrm{HBeAg}$-positive chronic hepatitis B. Hepatology 2007;45:1172-1178.

13 Yoo BC, Kim JH, Kim TH, Koh KC, Um SH, Kim YS, Lee, KS, Han BH, Chon CY, Han JY, Ryu SH, Kim HC, Byun KS, Hwang SG, Kim BI, Cho M, Yoo K, Lee HJ, Hwang JS, Kim YS, Lee YS, Choi SK, Lee YJ, Yang JM, Park JW Lee MS, Kim DG, Chung YH, Cho SH, Choi JY, Kweon YO, Lee HY, Jeong SH, Yoo HW, Lee HS: Clevudine is highly efficacious in hepatitis $\mathrm{B}$ e antigen-negative chronic hepatitis B with durable off-therapy viral suppression. Hepatology 2007;46:1041-1048.

14 Marcellin P, Mommeja-Marin H, Sacks SL, Lau GK, Sereni D, Bronowicki JP, Conway B, Trepo C, Blum MR, Yoo BC, Mondou E, Sorbel J, Snow A, Rousseau F, Lee HS: A phase II dose-escalating trial of clevudine in patients with chronic hepatitis B. Hepatology 2004; 40:140-148.
15 Lee HS, Chung YH, Lee KS, Byun KS, Paik SW, Han JY, Yoo K, Yoo HW, Lee JH, Yoo BC: A 12-week clevudine therapy showed potent and durable antiviral activity in $\mathrm{HBeAg}$-positive chronic hepatitis B. Hepatology 2006; 43:982-988.

$\checkmark 16$ Lee KS, Byun KS, Chung YH, Paik SW, Han JY, Yoo K, Yoo HW, Yoo BC, Lee HS: Clevudine therapy for 24 weeks further reduced serum hepatitis B virus DNA levels and increased ALT normalization rates without emergence of viral breakthrough than 12 weeks of clevudine therapy. Intervirology 2007;50:296-302.

$>17$ Lai CL, Leung N, Teo EK, Tong M, Wong F, Hann HW, Han S, Poynard T, Myers M, Chao G, Lloyd D, Brown NA, Telbivudine Phase II Investigator Group: A 1-year trial of telbivudine, lamivudine, and the combination in patients with hepatitis B e antigenpositive chronic hepatitis B. Gastroenterology 2005; 129:528-536.

18 Chang TT, Gish RG, de Man R, Gadano A, Sollano J, Chao YC, Lok AS, Han KH, Goodman Z, Zhu J, Cross A, DeHertogh D, Wilber R, Colonno R, Apelian D, BEHoLD AI463022 Study Group: A comparison of entecavir and lamivudine for $\mathrm{HBeAg-positive} \mathrm{chronic}$ hepatitis B. N Engl J Med 2006;354:10011010 .

19 Lai CL, Shouval D, Lok AS, Chang TT, Cheinquer H, Goodman Z, DeHertogh D, Wilber R, Zink RC, Cross A, Colonno R, Fernandes L, BEHoLD AI463027 Study Group: Entecavir versus lamivudine for patients with $\mathrm{HBeAg}$-negative chronic hepatitis B. N Engl J Med 2006;354:1011-1020.

20 Hadziyannis SJ, Tassopoulos NC, Heathcote EJ, Chang TT, Kitis G, Rizzetto M, Mercellin P, Lim SG, Goodman Z, Ma J, Arterburn S, Xiong S, Currie G, Brosgart CL, Adefovir Dipivoxil 438 Study Group: Long-term therapy with adefovir dipivoxil for HBeAg-negative chronic hepatitis B. N Engl J Med 2005; 352:2673-2681. 